\title{
Effects of essential oils of Rosmarinus officinalis Linn. and Origanum vulgare Linn. from different origins on Sporothrix brasiliensis and Sporothrix schenckii complex
}

\author{
[Efeitos dos óleos essenciais de Rosmarinus officinalis Linn. e Origanum vulgare Linn. de diferentes \\ origens em Sporothrix brasiliensis e complexo Sporothrix schenckii] \\ S.B. Waller ${ }^{1}$, I.M. Madrid ${ }^{2}$, M.B. Cleff ${ }^{1}$, R. Santin $^{3}$, R.A. Freitag ${ }^{1}$, \\ M.C.A. Meireles ${ }^{1}$, J.R.B. Mello ${ }^{4}$ \\ ${ }^{1}$ Universidade Federal de Pelotas - UFPel - Pelotas, RS \\ ${ }^{2}$ Prefeitura Municipal de Pelotas - Centro de Controle de Zoonoses - Pelotas, RS \\ ${ }^{3}$ Instituto Federal Catarinense - IFC - Concórdia, SC \\ ${ }^{4}$ Universidade Federal do Rio Grande do Sul - UFRGS - Porto Alegre, RS
}

\begin{abstract}
Rosmarinus officinalis L. (rosemary) and Origanum vulgare L. (oregano) are known to have antimicrobial properties, but studies on sporotrichosis are scarce. This study aimed to evaluate the antiSporothrix spp. activity of essential oils from commercial products and oils extracted from aerial parts of these plants and analyze their chemical constituents. S. schenckii complex and S. brasiliensis ( $n$ : 25) isolated from humans, cats, dogs, and environmental soil were tested through M27-A3 guidelines of CLSI with modification for phytotherapics. The essential oils of $R$. officinalis $\mathrm{L}$. were similar for $\mathrm{MIC}_{50}$ and $\mathrm{MFC}_{50} \leq 2.25 \mathrm{mg} / \mathrm{mL}$ for extracted oil; and $4.5 \mathrm{mg} / \mathrm{mL}$ and $9 \mathrm{mg} / \mathrm{mL}$, respectively, for commercial oil. Both products showed $\mathrm{MIC}_{90}$ of $18 \mathrm{mg} / \mathrm{mL}$ and $\mathrm{MFC}_{90}$ of $36 \mathrm{mg} / \mathrm{mL}$. In $O$. vulgare L., the extracted oil had better activity with $\mathrm{MIC}_{50}$ and $\mathrm{MFC}_{50} \leq 2.25 \mathrm{mg} / \mathrm{mL}$, and $\mathrm{MIC}_{90}$ and $\mathrm{MFC}_{90}$ of $4.5 \mathrm{mg} / \mathrm{mL}$, whereas the commercial oil showed $\mathrm{MIC}_{50}$ and $\mathrm{MFC}_{50}$ of $9 \mathrm{mg} / \mathrm{mL}$ and $\mathrm{MIC}_{90} 18 \mathrm{mg} / \mathrm{mL}$, respectively, and $\mathrm{MFC}_{90}$ of $36 \mathrm{mg} / \mathrm{mL}$. Through gas chromatography (CG/FID), thymol and $\alpha$-terpinene were majority for extracted oil of $O$. vulgare L., and carvacrol and $\gamma$-terpinene made up the majority of the commercial oil. Both essential oils of $R$. officinalis L. showed 1,8-cineole and $\alpha$-pinene as major. The fungal isolates were susceptible to all tested essential oils, including in itraconazole-resistant $S$. brasiliensis isolates. The extracted and commercial oils of the plants presented in vitro anti-Sporothrix spp. activity, and they are promising for treatment of sporotrichosis, including in cases refractory to itraconazole. More studies should be performed about toxicity and in vivo efficacy for its safe use.
\end{abstract}

Keywords: sporotrichosis, antifungal resistance, oregano, rosemary, Lamiaceae

\section{RESUMO}

Rosmarinus officinalis L. (alecrim) e Origanum vulgare L. (orégano) são conhecidos pelas propriedades antimicrobianas, entretanto seus estudos na esporotricose são escassos. Este trabalho objetivou avaliar a atividade anti-Sporothrix spp. de óleos extraídos e comerciais dessas plantas e analisar seus constituintes químicos. Isolados do complexo $\mathrm{S}$. schenckii e $\mathrm{S}$. brasiliensis (n: 25) de humanos, gatos, cães e solo, foram testados pela diretriz M27-A3 do CLSI com modificações para fitoterápicos. Os óleos de R. officinalis L. foram similares com CIM fo $_{\text {e }}$ CFM $M_{50} \leq 2.25 \mathrm{mg} / \mathrm{mL}$ para extraído; e $4.5 \mathrm{mg} / \mathrm{mL}$ e $9 \mathrm{mg} / \mathrm{mL}$, respectivamente, para comercial. Ambos os produtos demonstraram $C_{90}$ de $18 \mathrm{mg} / \mathrm{mL}$ e $\mathrm{CFM}_{90}$ de $36 \mathrm{mg} / \mathrm{mL}$. Em O. vulgare L., o óleo extraído apresentou melhor atividade com CIM So $e$ $\mathrm{CFM}_{50} \leq 2.25 \mathrm{mg} / \mathrm{mL}$ e $\mathrm{CIM}_{90}$ e CFM $\mathrm{CH}_{90}$ de $4.5 \mathrm{mg} / \mathrm{mL}$, ao passo que o óleo comercial mostrou CIM ${ }_{50} e$ $\mathrm{CFM}_{50}$ de $9 \mathrm{mg} / \mathrm{mL} ;$ e $\mathrm{CIM}_{90}$ de $18 \mathrm{mg} / \mathrm{mL}$ e CFM $\mathrm{CO}_{90}$ de $36 \mathrm{mg} / \mathrm{mL}$. Por meio da cromatografia gasosa $(C G / F I D)$, timol e $\alpha$-terpineno foram majoritários para o óleo extraído de $\mathrm{O}$. vulgare L., e carvacrol e $\gamma$ terpineno para o comercial. Ambos os óleos de R. officinalis L. apresentaram 1,8-cineol e $\alpha$-pineno como

Recebido em 20 de agosto de 2015

Aceito em 15 de fevereiro de 2016

E-mail: waller.stefanie@yahoo.com.br 
prevalentes. Os isolados foram sensíveis a todos os óleos essenciais testados, inclusive S. brasiliensis, resistentes ao itraconazol. Os óleos extraídos e comerciais de R. officinalis $L$. e O. vulgare $L$. apresentaram atividade anti-Sporothrix spp. in vitro e são promissores para o tratamento da esporotricose, inclusive em casos refratários ao itraconazol. Mais estudos devem ser realizados sobre toxicidade e eficácia in vivo para seu uso seguro.

Palavras-chave: esporotricose, resistência antifúngica, orégano, alecrim, Lamiaceae

\section{INTRODUCTION}

Sporotrichosis is a worldwide mycosis in humans and animals with importance in public health and has as etiological agents the species of Sporothrix schenckii complex (Marimon et al., 2007, 2008; Pereira et al., 2010). In Brazil, Sporothrix brasiliensis has been isolated in cats, and this species has been restricted to this geographic region (Rodrigues et al., 2013; Montenegro et al., 2014). The treatment of choice in humans and animals is recommended with itraconazole due to its efficacy and therapeutic safety, but the emergence of resistant strains has been reported (Marimon et al., 2008; Pereira et al., 2010; Rodrigues et al., 2014a). This problem has stimulated the search for new effective chemical compounds, such as in plants extracts, and their use in popular medicine to treat, cure, and prevent diseases is one of the most ancient human practices (Veiga Jr. et al., 2005; Jiang et al., 2011; Vale-Silva et al., 2012).

In the Lamiaceae family, rosemary (Rosmarinus officinalis L.) and oregano (Origanum vulgare L.) are aromatic plants that are widely used in the culinary arts and have therapeutic applications, and they produce essential oils containing phenolic compounds that are highly related to antimicrobial properties (Bozin et al., 2007; Luqman et al., 2007). Commercial oils and oils extracted from aerial parts of these plants have been used to combat several fungal pathogens of medical and veterinary interest (Luqman et al., 2007; Cleff et al., 2010; Souza et al., 2010). For therapeutic use, the acquisition of commercials oils is easier than the trouble of sending plant material for extraction in chemical laboratories. However, the quality of the commercial product should be controlled because adulteration can cause therapeutic inefficiency and even side effects, such as the mixture of volatile oils with different qualities to promote higher yield (Simões et al., 2003; Veiga Jr. et al., 2005).
The few studies with commercial oils of $R$. officinalis L. and $O$. vulgare L. have also proven the good in vitro activity against fungal pathogens (Moreira et al., 2012; Abrantes et al., 2013; Cleff et al., 2013), but in Sporothrix spp., the studies concentrate on products extracted from plants collected in natura or acquired commercially (Luqman et al., 2007; Cleff et al., 2008, 2010). No scientific studies on the use of these commercial oils to treat sporotrichosis exist. This study aimed to evaluate and compare the in vitro antifungal activity of the essential oils of commercial origin and extracted from aerial parts of $R$. officinalis L. and $O$. vulgare L. against isolates of Sporothrix brasiliensis and Sporothrix schenckii complex, as well as to analyze their chemical constituents.

\section{MATERIALS AND METHODS}

For the experiment aerial parts of $O$. vulgare $\mathrm{L}$. and $R$. officinalis L. were acquired with botanical certifications and originated from Chile (process $n^{\circ} 23110.001622 / 2012-55$ of the Comissão de Ética em Experimentação Animal, Universidade Federal de Pelotas), (Luar Sul® - Indústria e Comércio de Produtos Alimentícios Ltda., Santa Cruz do Sul, RS, Brazil). The plant materials were submitted for extraction via distillation by steam dragging in Clevenger equipment for 4 hours, according to Farmacopéia Brasileira (1988). Subsequently, the oils were dried over $\mathrm{Na}_{2} \mathrm{SO}_{4}$ (anhydrous sodium sulfate p.a), concentrated in $\mathrm{N}_{2}$ (ultra pure, $99.99 \%$, White Martins) and stored in amber vials under refrigeration. In turn, the commercial oils (Ferquima ${ }^{\circledR}$ - Indústria e Comércio Ltda., Vargem Grande Paulista, SP, Brazil) were acquired with botanical certification and origin from Moldavia (Batch 212 for oregano) and Tunisia (Batch 141 for rosemary) and were extracted via distillation by steam dragging. The quality parameters were described in an accompanying technical report (appearance, color, purity, odor, density $-20^{\circ} \mathrm{C}$, refraction index $-20^{\circ} \mathrm{C}$ ). 
The extracted oils were chemically analyzed through high-resolution gas chromatography with a flame ionization detector (CG-FID) in a Shimadzu® 2010 model equipped with a DB-5 silica column $(30 \mathrm{~m} \times 0.25 \mathrm{~mm} \times 0.25 \mu \mathrm{m})$ at an initial temperature of $40^{\circ} \mathrm{C}$, which was increased at the rate of $2^{\circ} \mathrm{C} / \mathrm{min}$ up $145^{\circ} \mathrm{C}$. From then on the rate was increased by $10^{\circ} \mathrm{C} / \mathrm{min}$ up to $280^{\circ} \mathrm{C}$ and remained at this temperature for $10 \mathrm{~min}$. The oil solutions were prepared at $5000 \mathrm{mg} / \mathrm{L}$ in hexane and the chromatographic standards at $40 \mathrm{mg} / \mathrm{L}$ and were injected into the chromatographic column at a volume of $1 \mu \mathrm{L}$, and the compounds were identified by comparison of the retention time. For commercial oils, the CG-FID was performed by HP 7820A (Agilent ${ }^{\circledR}$ ) equipped with an HP-5 column $(30 \mathrm{~m} \times 0.32 \mathrm{~mm} \times 0.25 \mathrm{~mm})$ at an initial temperature of $70^{\circ} \mathrm{C}$ that was increased by $3^{\circ} \mathrm{C} / \mathrm{min}$ up to $240^{\circ} \mathrm{C}$. The injector temperature was $250^{\circ} \mathrm{C}$, and the FID detector was $260^{\circ} \mathrm{C}$. The speed of the drag hydrogen gas was $3 \mathrm{ml} / \mathrm{min}$, and the split was 1:30. The solutions of essential oils were diluted in $1 \%$ chloroform and injected into the chromatograph volume of $1 \mu \mathrm{L}$. Data were acquired through the EZChrom Elite Compact ${ }^{\circledR}$ program (Agilent $\AA$ ).

Twenty-five samples of Sporothrix schenckii complex were derived from mycology collection of the Centro de Pesquisa e Diagnóstico em Micologia Veterinária (Universidade Federal de Pelotas - UFPEL, Pelotas, RS, Brazil). The isolates were derived from clinical cases of humans, dogs, and cats with sporotrichosis and an environmental soil isolate, as well as a standard strain (IOC 1226). All isolates were identified and stored in the mycelial phase in potato-dextrose agar (Acumedia, Lansing, Michigan, Unites States) and refrigerated at an average temperature of $4^{\circ} \mathrm{C}$. Fourteen of these were analyzed through polymerase chain reaction of restriction fragment length polymorphism (PCR-RFLP), according to Rodrigues et al. (2014b), and all were identified as Sporothrix brasiliensis.

The antifungal activity was determined through the broth microdilution technique in microplates with 96-wells and in duplicate, according to the M27-A3 guidelines (Reference..., 2008a), which were adapted for use with essential oils (Cleff et al., 2008). Fungal subcultures in brain-heartinfusion agar (BHI/Acumedia, Lansing,
Michigan, United States) at $35^{\circ} \mathrm{C}$ for $48 \mathrm{~h}$ were performed to activate the yeast phase of Sporothrix spp. The essential oils were tested in concentrations of 2.25 to $72 \mathrm{mg} / \mathrm{mL}$. Itraconazole (Cepav Pharma Ltda., São Paulo, SP, Brazil) was utilized for positive control and tested in concentrations of 0.03 to $16 \mu \mathrm{g} / \mathrm{mL}$, according to CLSI guidelines. The microplates were incubated at $35^{\circ} \mathrm{C}$ for $72 \mathrm{~h}$ to obtain the minimal inhibitory concentration (MIC), and the microplates were put on a rotatory shaker (Certomat ${ }^{\circledR}$ BS-1, B. Sartorius, Göttingen, Germany) to mix the oils. To obtain the minimal fungicidal concentration (MFC), $10 \mu \mathrm{L}$ of aliquots of the wells with no fungal growth were transferred to Petri dishes containing Sabouraud dextrose agar (Acumedia, Lansing, Michigan, United States) and incubated at $35^{\circ} \mathrm{C}$ for $72 \mathrm{~h}$ to visualize fungal growth. The analysis of variance and comparison of geometric means of the data were performed according to the Tukey test using the statistical software BioEstat ${ }^{\circledR}$, version 5.3, and a value of $\mathrm{P}<0.05$ was considered significant.

\section{RESULTS AND DISCUSSION}

The MIC of itraconazole for tested isolates overall varied from equal to or less than 0.03 to greater than $16 \mu \mathrm{g} / \mathrm{mL}$, and the MFC varied from 0.25 to greater than $16 \mu \mathrm{g} / \mathrm{mL}$. However, one isolate from a cat was resistant to MIC, and five from cats and one from a dog were to MFC (Tab. 1). Although a cutoff point does not exist for establishing the values of resistance, the M38-A2 guidelines (Reference..., 2008b) suggest that MIC values greater than or equal to $4 \mu \mathrm{g} / \mathrm{mL}$ for itraconazole should be considered, and this was observed in the tested $S$. brasiliensis from cats $\left(\mathrm{MIC}_{90}\right.$ of $\left.16 \mu \mathrm{g} / \mathrm{mL}\right)$, which demonstrated a low sensibility to this drug of choice. This observation was also reported (Fernandes et al., 2013; Rodrigues et al., 2014a). Interestingly, all of the itraconazole-resistant isolates were susceptible to the essential oils of the Lamiaceae plants between the concentrations of $\leq 2.25$ and $36 \mathrm{mg} / \mathrm{mL}$, and this is accordance with studies of the activity of these oils in bacterial and fungal resistance to ciprofloxacin, amphotericin B and clotrimazole (Luqman et al., 2007; Maida et al., 2014).

In $O$. vulgare L., the extracted oil showed activity against all samples of $S$. schenckii complex in the $\mathrm{MIC}_{50 / 90}$ and $\mathrm{MFC}_{50 / 90}$ between 
$\leq 2.25$ and $4.5 \mathrm{mg} / \mathrm{mL}$, including in $S$. brasiliensis from cats and dogs. But, the commercial oil showed activity against the overall isolates with

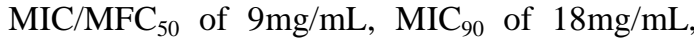

and $\mathrm{MFC}_{90}$ of $36 \mathrm{mg} / \mathrm{mL}$, demonstrating less activity compared to the extracted essential oil $(\mathrm{P}<0.05)$.

Table 1. Antifungal activity of the extracted and commercial essential oils $(\mathrm{mg} / \mathrm{mL})$ of Origanum vulgare L. (O.V.) and Rosmarinus officinalis L. (R.O.) and itraconazole ( $\mu \mathrm{g} / \mathrm{mL})$ against Sporothrix schenckii complex

\begin{tabular}{|c|c|c|c|c|c|c|c|c|c|c|c|}
\hline \multirow{2}{*}{\multicolumn{2}{|c|}{$\begin{array}{l}\text { Origin of Sporothrix } \\
\text { schenckii complex (No. of } \\
\text { samples) }\end{array}$}} & \multicolumn{2}{|c|}{$\begin{array}{c}\text { O.V. } \\
\text { (Extracted) }\end{array}$} & \multicolumn{2}{|c|}{ O.V. (Commercial) } & \multicolumn{2}{|c|}{$\begin{array}{c}\text { R.O. } \\
\text { (Extracted) }\end{array}$} & \multicolumn{2}{|c|}{ R.O. (Commercial) } & \multicolumn{2}{|c|}{ Itraconazole } \\
\hline & & MIC & MFC & MIC & MFC & MIC & MFC & MIC & MFC & MIC & MFC \\
\hline \multirow{3}{*}{ Human $(3) \dagger$} & $\mathrm{R}$ & $\leq 2.25$ & $\leq 2.25-4.5$ & 18 & 18 & $\leq 2.25-4.5$ & $\leq 2.25-4.5$ & $\leq 2.25-9$ & $\leq 2.25-18$ & 0.5 & $0.5-2$ \\
\hline & $50 \%$ & $\leq 2.25$ & 4.5 & 18 & 18 & $\leq 2.25$ & $\leq 2.25$ & $\leq 2.25$ & $\leq 2.25$ & 0.5 & 1 \\
\hline & $90 \%$ & $\leq 2.25$ & 4.5 & 18 & 18 & 4.5 & 4.5 & 9 & 18 & 0.5 & 2 \\
\hline $\operatorname{Dog}(1) \dagger$ & $\mathrm{R}$ & $\leq 2.25$ & $\leq 2.25$ & 4.5 & 4.5 & $\leq 2.25$ & 4.5 & 4.5 & 9 & 1 & 2 \\
\hline \multirow{3}{*}{ Cat (5) $\dagger$} & $\mathrm{R}$ & $\leq 2.25-4.5$ & $\leq 2.25-9$ & $\leq 2.25-18$ & $\leq 2.25-36$ & $\leq 2.25-18$ & $\leq 2.25-18$ & $\leq 2.25-9$ & $4.5-18$ & $2 \rightarrow 16$ & $4 \rightarrow 16$ \\
\hline & $50 \%$ & $\leq 2.25$ & $\leq 2.25$ & 4.5 & 9 & $\leq 2.25$ & 18 & 4.5 & 4.5 & 2 & $>16$ \\
\hline & $90 \%$ & $\leq 2.25$ & 4.5 & 9 & 18 & 18 & 18 & 4.5 & 9 & 2 & $>16$ \\
\hline Soil $(1) \dagger$ & $\mathrm{R}$ & $\leq 2.25$ & $\leq 2.25$ & 18 & 18 & $\leq 2.25$ & $\leq 2.25$ & 9 & 18 & 0.5 & 0.5 \\
\hline IOC $1226(1)^{*}$ & $\mathrm{R}$ & $\leq 2.25$ & $\leq 2.25$ & $\leq 2.25$ & $\leq 2.25$ & $\leq 2.25$ & $\leq 2.25$ & 18 & 36 & 1 & 8 \\
\hline \multirow{3}{*}{$\operatorname{Dogs}(6)^{* *}$} & $\mathrm{R}$ & $\leq 2.25$ & $\leq 2.25-4.5$ & $\leq 2.25-36$ & $\leq 2.25-36$ & $\leq 2.25$ & $\leq 2.25-4.5$ & $\leq 2.25-18$ & $4.5->72$ & $0.5-8$ & $1->16$ \\
\hline & $50 \%$ & $\leq 2.25$ & $\leq 2.25$ & $\leq 2.25$ & 4.5 & $\leq 2.25$ & $\leq 2.25$ & 4.5 & 9 & 1 & 2 \\
\hline & $90 \%$ & $\leq 2.25$ & $\leq 2.25$ & 9 & 18 & $\leq 2.25$ & 4.5 & 18 & 36 & 2 & 16 \\
\hline \multirow{3}{*}{ Cats $(8)^{* *}$} & $\mathrm{R}$ & $\leq 2.25-9$ & $\leq 2.25-9$ & $\leq 2.25-18$ & $\leq 2.25-36$ & $\leq 2.25-18$ & $\leq 2.25-72$ & $\leq 2.25-9$ & $\leq 2.25-9$ & $\leq 0.03-16$ & $0.25->16$ \\
\hline & $50 \%$ & $\leq 2.25$ & $\leq 2.25$ & 9 & 9 & $\leq 2.25$ & $\leq 2.25$ & $\leq 2.25$ & 4.5 & 2 & 2 \\
\hline & $90 \%$ & 4.5 & 4.5 & 18 & 18 & 18 & 36 & 4.5 & 4.5 & 16 & $>16$ \\
\hline \multirow{3}{*}{ Overall (25) } & $\mathrm{R}$ & $\leq 2.25-9$ & $\leq 2.25-9$ & $\leq 2.25-36$ & $\leq 2.25-36$ & $\leq 2.25-18$ & $\leq 2.25-72$ & $\leq 2.25-18$ & $\leq 2.25->72$ & $\leq 0.03->16$ & $0.25 \rightarrow 16$ \\
\hline & $50 \%$ & $\leq 2.25$ & $\leq 2.25$ & 9 & 9 & $\leq 2.25$ & $\leq 2.25$ & 4.5 & 9 & 2 & 4 \\
\hline & $90 \%$ & 4.5 & 4.5 & 18 & 36 & 18 & 36 & 18 & 36 & 16 & $>16$ \\
\hline
\end{tabular}

$50 \%$ and $90 \%$ refers to inhibition (MIC) and elimination (MFC) of the fungal growth in relation of origin of the isolates ; $\mathrm{R}$ - Range; $*$ S. schenckii; $* * S$. brasiliensis; $\uparrow$ Not identified.

Few studies have also demonstrated the susceptibility of $S$. schenckii to the extracted oil of $O$. vulgare L. at MIC of $250 \mu \mathrm{L} / \mathrm{mL}$ (Cleff et al., 2008) and between 250 to $500 \mu \mathrm{L} / \mathrm{mL}$ (Cleff et al., 2010), but the expression of these values was distinct from the present study, making it difficult to compare the results. This difficulty occurs because of the lack of standardization in antimicrobial in vitro tests with medicinal plants (Khan et al., 2011). Even so, the studies are in agreement with the present finding because of the anti-Sporothrix spp. activity of the essential oil of $O$. vulgare $\mathrm{L}$. In other pathogenic fungi, the extracted oil of $O$. vulgare L. inhibited Malassezia pachydermatis, Aspergillus spp., Candida spp., Cryptococcus spp., Trichophyton spp., Microsporum spp., and Epidermophyton spp. in the MIC between 15 to $500 \mu \mathrm{L} / \mathrm{mL}$ (Cleff et al., 2010) and between 0.32 to $10 \mu \mathrm{L} / \mathrm{mL}$ (Vale-Silva et al., 2012). In commercial oils, $M$. pachydermatis strains were inhibited by the essential oil of $O$. vulgare L. between the MIC of $\leq 1.87$ to $7 \mathrm{mg} / \mathrm{mL}$ (Santin et al., 2014), with similar results to this study. The antimicrobial activity of the commercial oils should be studied because these products are easier to acquire for popular use and showed in vitro anti-Sporothrix spp. activity, which is promising for more scientific research.

In $R$. officinalis L., the commercial and extracted essential oils showed similar anti-Sporothrix spp. activity $(\mathrm{P}>0.05)$. The $\mathrm{MIC}_{50}$ of extracted oil against overall tested isolates was $\leq 2.25 \mathrm{mg} / \mathrm{mL}$, but the $\mathrm{MIC}_{90}$ and $\mathrm{MFC}_{90}$ of $S$. schenckii complex isolated from humans were $4.5 \mathrm{mg} / \mathrm{mL}$ and from cats were $18 \mathrm{mg} / \mathrm{mL}$. Although the $\mathrm{MIC}_{90}$ and $\mathrm{MFC}_{90}$ of $S$. brasiliensis from dogs were $\leq 2.25 \mathrm{mg} / \mathrm{mL}$ and $4.5 \mathrm{mg} / \mathrm{mL}$, respectively, and those from cats were $18 \mathrm{mg} / \mathrm{mL}$ and $36 \mathrm{mg} / \mathrm{mL}$, respectively, no statistical difference was observed in the activity of extracted oil for these species $(\mathrm{P}>0.05)$. Luqman et al. (2007) demonstrated the anti-Sporothrix spp. activity of the extracted oil with the same methodology used in our study and described the MIC of $11 \mathrm{mg} / \mathrm{mL}$ in an only $S$. schenckii strain tested, and the plant did not show fungicidal activity. The fungistatic activity found by Luqman et al. (2007) was similar to our study, but our results 
showed the effect of $\mathrm{MFC}_{50}$ and $\mathrm{MFC}_{90}$ against overall tested isolates at $\leq 2.25 \mathrm{mg} / \mathrm{mL}$ and $36 \mathrm{mg} / \mathrm{mL}$ for extracted oil, respectively, and $9 \mathrm{mg} / \mathrm{mL}$ and $36 \mathrm{mg} / \mathrm{mL}$ for commercial oils, demonstrating the good fungicidal activity of the essential oil of $R$. officinalis L. Other pathogenic fungi have been highly susceptible to rosemary oil, as Candida albicans (Bozin et al., 2007; Cleff et al., 2012), that was inhibited and eliminated by the plant oil at $5.5 \mathrm{mg} / \mathrm{mL}$ and $11 \mathrm{mg} / \mathrm{mL}$, respectively, as well as Crytococcus neoformans (Luqman et al., 2011). The dermatophytes Epidermophyton floccosum, Trichophyton mentagrophytes, T. rubrum and Microsporum canis were susceptible in the MIC of 15 to $30.2 \mu \mathrm{L} / \mathrm{mL}$ (Bozin et al., 2007) and $T$. rubrum and $M$. gypseum were inhibited at $1.38 \mathrm{mg} / \mathrm{mL}$ and $2.75 \mathrm{mg} / \mathrm{mL}$, respectively (Luqman et al., 2007).

In turn, the commercial oil of $R$. officinalis $\mathrm{L}$. had in vitro activity with $\mathrm{MIC}_{50}$ between $\leq 2.25$ and $4.5 \mathrm{mg} / \mathrm{mL}$ for all isolates from humans, dogs, and cats. In $\mathrm{MIC}_{90}$, the concentration of 4.5 to $18 \mathrm{mg} / \mathrm{mL}$ inhibited all $S$. brasiliensis and $S$. schenckii complex, including environmental soil and standard strain. The $\mathrm{MFC}_{50}$ and $\mathrm{MFC}_{90}$ of overall isolates were $9 \mathrm{mg} / \mathrm{mL}$ and $36 \mathrm{mg} / \mathrm{mL}$, respectively. With similar results, Santin (2013) showed the in vitro activity of commercial oil of $R$. officinalis L. against the pathogenic yeasts of $M$. pachydermatis, Candida spp. and Trichosporon asahii in the MIC/MFC between $\leq 1.87$ and $30 \mathrm{mg} / \mathrm{mL}$, demonstrating the promising use of this plant oil in similar concentrations to our study. Although the studies were concentrated in essential oils extracted from collected plants, the need to study the antimicrobial activity of commercial oils is emphasized because they are readily available for use. According to Veiga Jr. et al. (2005), the popular use of medicinal plants is increasingly common because of their benefits to public health, as well as being marketed by industries.

In $S$. brasiliensis isolated from cats and dogs, all of the isolates were susceptible to all of the tested oils, but a higher number of the isolates were susceptible to the $\mathrm{MIC} \leq 2.25 \mathrm{mg} / \mathrm{mL}$ from the extracted oils of $R$. officinalis L. and $O$. vulgare L. (Fig. 1).

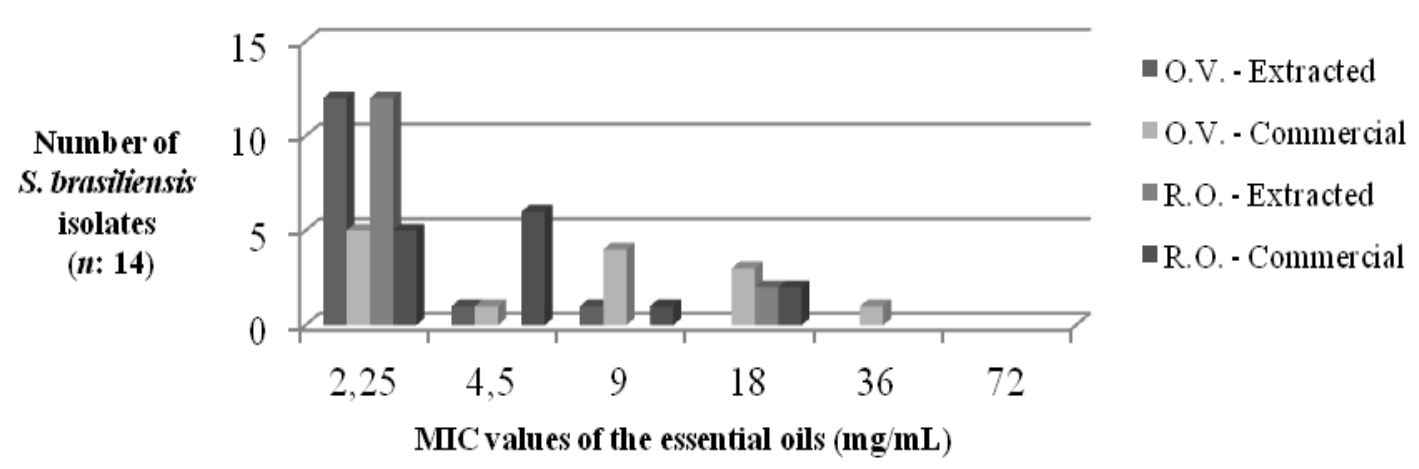

Figure 1. Number of Sporothrix brasiliensis isolated from cats and dogs with susceptibility to minimal inhibitory concentration (MIC) of commercial oils and extracted oils from aerial parts of Origanum vulgare L. (O.V.) and Rosmarinus officinalis L. (R.O.).

In the chromatographic analysis, both essential oils of $R$. officinalis L. showed that 1.8-cineole and $\alpha$-pinene were the major compounds (Figure 2 and 3), which is in accordance with previous studies (Jiang et al., 2011; Maida et al., 2014). These compounds were also related to antimicrobial potential because they both showed activity against $C$. albicans when tested in isolation at MIC of $0.5 \%$ (Jiang et al., 2011). Other compounds found in the oils were reported as major compounds, such as camphor, verbenone, and myrcene (Prins et al., 2006; Cleff et al., 2012), and could also be responsible for antifungal properties. 


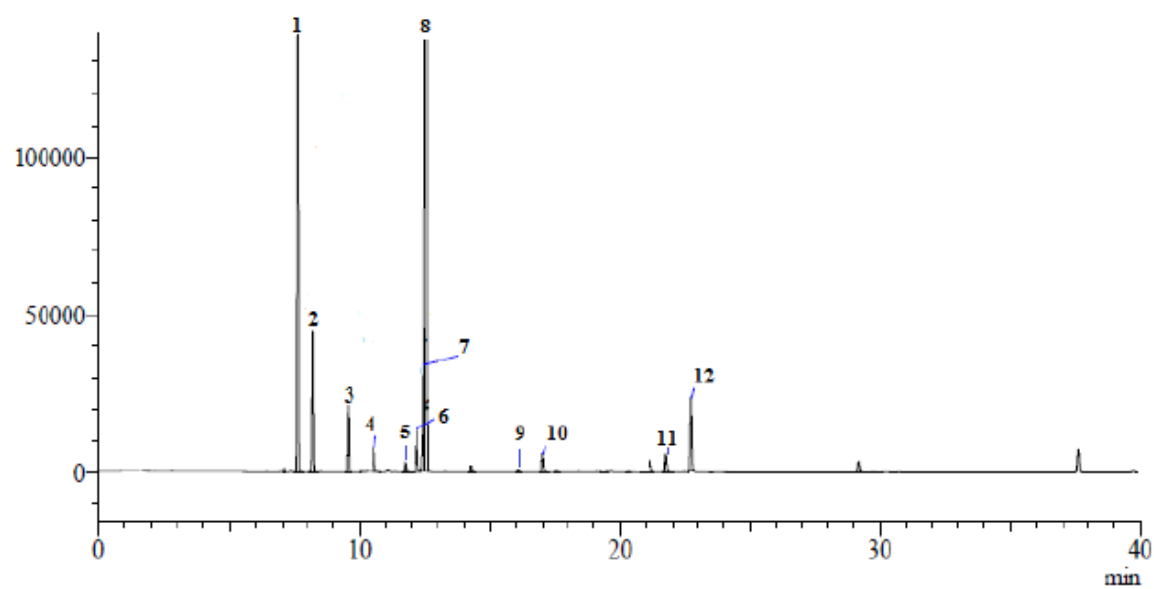

Figure 2. Identified compounds in the extracted essential oil from aerial parts of Rosmarinus officinalis L. through gas chromatograph with flame ionization detector (CG-FID): $\alpha$-pinene (1), camphene (2), $\beta$ pinene (3), myrcen (4), $\alpha$-terpinene (5), p-cimene (6), limonene (7), 1,8-cineole (8), terpinolene (9), linalool (10), terpinen-4-ol (11), $\alpha$-terpineol (12).

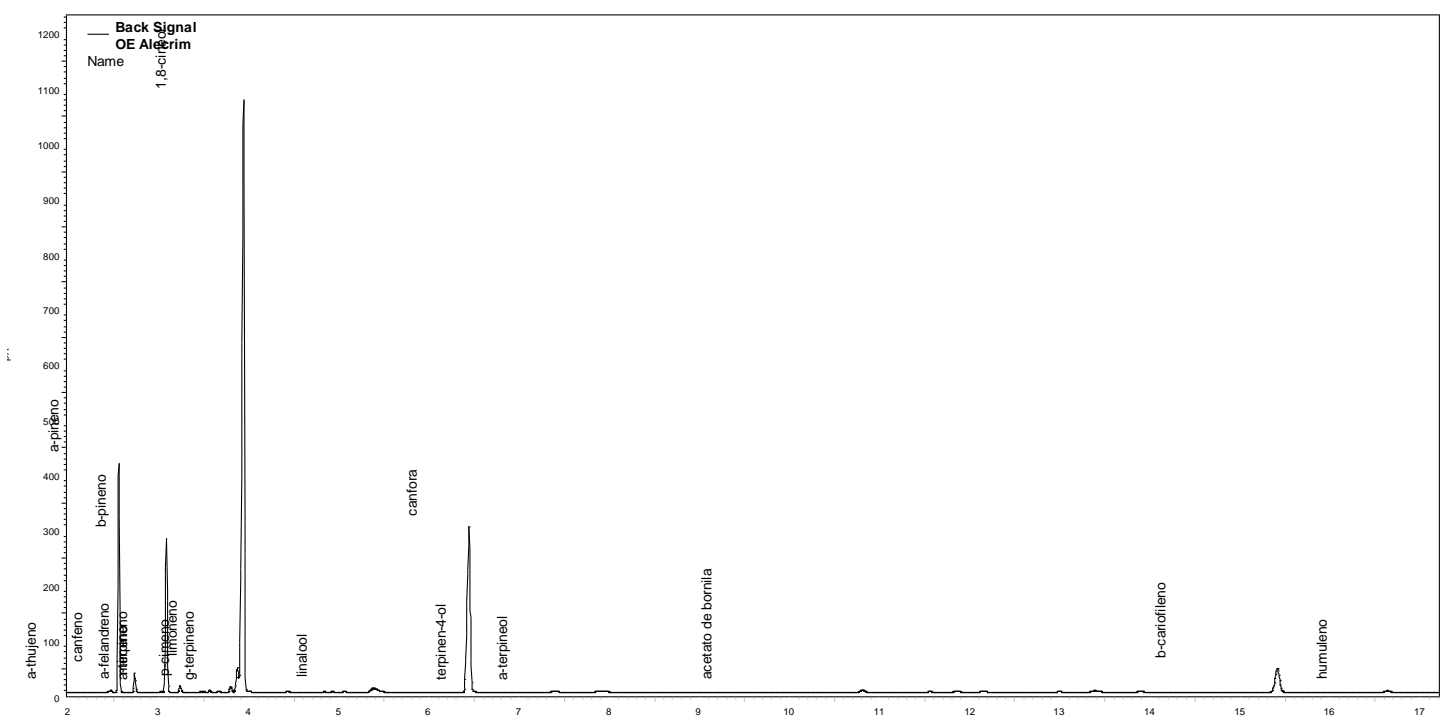

Figure 3. Identified constituents in the commercial essential oil of Rosmarinus officinalis L. through the gas chromatograph with flame ionization detector (CG-FID): $\alpha$-thujene, $\alpha$-pinene, camphene, $\beta$-pinene, myrcen, $\alpha$-phellandrene, $\alpha$-terpinene, p-cimene, limonene, 1,8-cineole, $\gamma$-terpinene, linalool, camphor, terpinen-4-ol, $\alpha$-terpineol, bornyl acetate, $\alpha$-copaene, $\beta$-caryophillene, humulene and others.

In O. vulgare L., the chemical composition was different, as well as the anti-Sporothrix spp. activity between the oils, in which the extracted oil from aerial parts had better efficacy than commercial oil $(\mathrm{P}<0.05)$. In extracted oil, thymol, $\alpha$-terpinene and 4-terpineol were the major compounds, in decreasing order (Figure 4), as well as described by Cleff et al. (2008, 2010), but in commercial oil, the compounds carvacrol, $\gamma$-terpinene and $p$-cimene were major
(Figure 5), according to Maida et al. (2014). Although thymol and carvacrol were found in larger quantities, respectively, for extracted oil from Chile and for commercial oil from Moldavia, both substances are responsible for antifungal activity. Chavan and Tupe (2014) reported that these substances provoke membrane damage and leakage of fungal cytoplasm as primary antifungal mechanism and consequently the ergosterol depletion. 


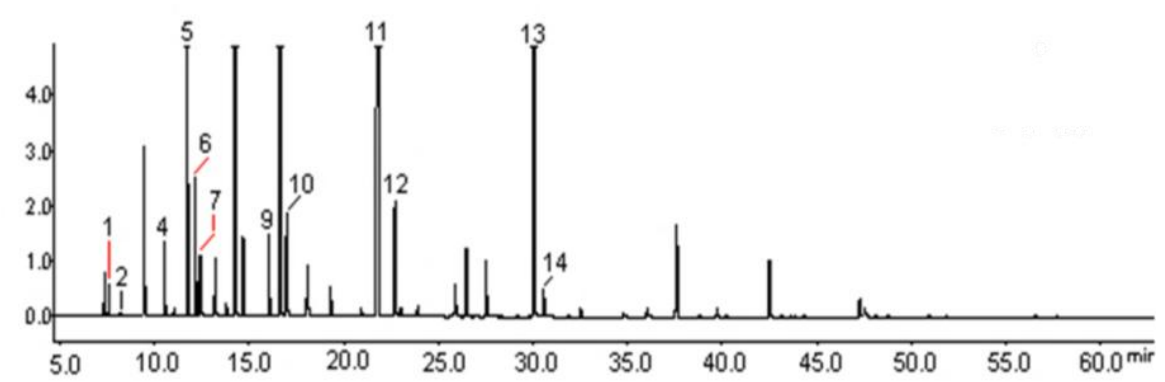

Figure 4. Identified constituents of the extracted essential oil from aerial parts of Origanum vulgare L. through gas chromatograph with flame ionization detector (CG-FID): $\alpha$-pinene (1), camphene (2), $\beta$ pinene (3), myrcene (4), $\alpha$-terpinene (5), p-cimene (6), limonene (7), 1,8-cineole (8), terpinolene (9), linalool (10), terpinen-4-ol (11), $\alpha$-terpineol (12), thymol (13) and carvacrol (14).

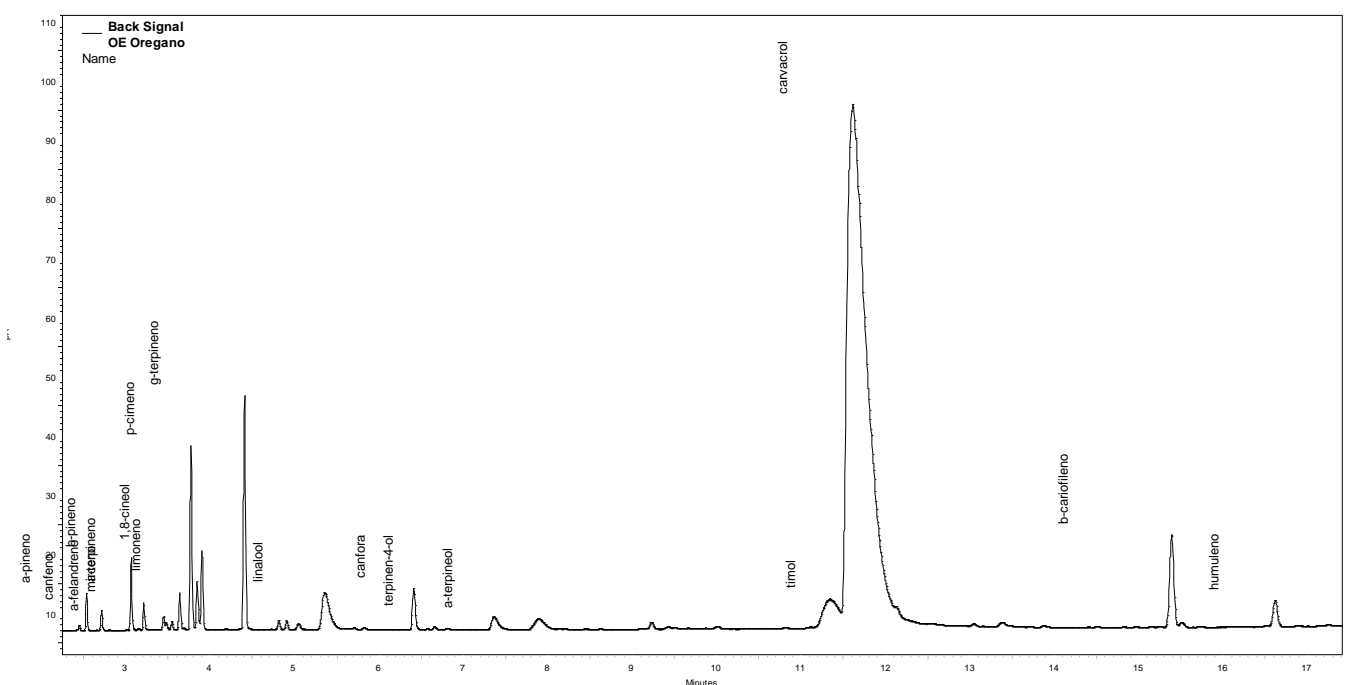

Figure 5. Identified constituents in the commercial essential oil of Origanum vulgare L. by gas chromatograph in high resolution with flame ionization detector (CG-FID): $\alpha$-pinene, camphene, $\beta$ pinene, myrcene, $\alpha$-phellandrene, $\alpha$-terpinene, $\mathrm{p}$-cimene, limonene, 1,8-cineole, $\gamma$-terpinene, linalool, camphor, terpinen-4-ol, $\alpha$-terpineol, thymol, carvacrol, $\beta$-caryophyllene, humulene and others.

This difference in the chemical compositions of extracted and commercial products is influenced by several factors relating to plant and cultivation (Simões et al., 2003; Prins et al., 2006), such as the origin of the plant. The commercial oils of $O$. vulgare L. and $R$. officinalis L. came from Moldavia (Eastern Europe) and Tunisia (North Africa), respectively, while the extracted oils came from aerial parts collected in Chile (South America). Even so, all tested fungal isolates were susceptible to the two tested plants, regardless of their origin, including the commercial oils, which showed satisfactory activity against itraconazole-resistant isolates. Studies of commercial oils should be performed because the quality of these products could influence their antimicrobial activity. According to Simões et al. (2003) and Veiga Jr. et al. (2005), the control of the commercial oils in the industry should be rigorous because adulterations may occur and compromise the chemical composition and, consequently, harm the therapeutic efficiency, such as the addition of compounds with low financial value and the mixture of volatile oils with different qualities for promoting greater yield.

\section{CONCLUSION}

In the essential oils of $R$. officinalis L. and $O$. vulgare L. from different regions, the antiSporothrix spp. activity was observed, including 
against itraconazole-resistant $S$. brasiliensis isolates. The chemical composition between the oils extracted from aerial parts of the plants and the oils acquired commercially was similar. In $R$. officinalis L., 1,8-cineole was the major compound for both oils, that presented similar anti-Sporothrix spp. activity. In turn, the majoritary composition in the oils of $O$. vulgare L. was different, where thymol was largely found in extracted oil and showed better antiSporothrix spp. activity in relation to the carvacrol, that was largely found in the commercial oil. These findings encourage the promising use of these natural products in the treatment of humane and animal sporotrichosis and more studies need to be undertaken for their use in vivo to be safe.

\section{ACKNOWLEDGMENTS}

We are gratefull to Z.P. de Camargo (Universidade Federal de São Paulo, UNIFESP, São Paulo, SP, Brazil) for the biomolecular analysis of Sporothrix spp. isolates; to V. Ferraz (Universidade Federal de Minas Gerais, UFMG, Belo Horizonte, MG, Brazil) for chemical analysis of the commercial oils. We also thank CNPq, CAPES and FAPERGS for financial support.

\section{REFERENCES}

ABRANTES, M.R.; LIMA, E.O.; MEDEIROS, M.A.P. et al. Atividade antifúngica de óleos essenciais sobre leveduras Candida não albicans. Rev. Bras. Farm., v.94, p.227-233, 2013.

BOZIN, B.; MIMICA-DUKIN, N.; SAMOJLIK, I.; JOVIN, E. Antimicrobial and antioxidant properties of rosemary and sage (Rosmarinus officinalis L. and Salvia officinalis L., lamiaceae) essential oils. J. Agric. Food Chem., v.55, p.7879-7885, 2007.

CHAVAN, P.S.; TUPE, S.G. Antifungal activity and mechanism of action of carvacrol and thymol against vineyard and wine spoilage yeasts. Food Control., v.46, p.115-120, 2014.

CLEFF, M.B.; MADRID, I.M.; MEINERZ, A.R. et al. Essential oils against Candida spp: in vitro antifungal activity of Origanum vulgare. Afr. J. Microbiol. Res., v.7, p.2245-2250, 2013.

CLEFF, M.B.; MEINERZ, A.R.; FARIA, R.O. et al. Atividade inibitória do óleo essencial de orégano em fungos de importância médica e veterinária. Arq. Bras. Med. Vet. Zootec., v.62, p.1291-1294, 2010.

CLEFF, M.B.; MEINERZ, A.R.M.; MADRID, I. et al. Perfil de suscetibilidade de leveduras do gênero Candida isoladas de animais ao óleo essencial de Rosmarinus officinalis L. Rev. Bras. Plant. Med., v.14, p.43-49, 2012.

CLEFF, M.B.; MEINERZ, A.R.M.; SCHUCH, L.F.D. et al. Atividade in vitro do óleo essencial de Origanum vulgare frente à Sporothrix schenckii. Arq. Bras. Med. Vet. Zootec., v.60, p.513-516, 2008.

FARMACOPÉIA BRASILEIRA. 4.ed. São Paulo: Atheneu, 1988, parte I.

FERNANDES, G.F.; DOS SANTOS, P.O.; RODRIGUES, A.M. et al. Characterization of virulence profile, protein secretion and immunogenicity of different Sporothrix schenckii sensu stricto isolates compared with $S$. globosa and $S$. brasiliensis species. Virulence, v.4, p.241249, 2013.

JIANG, Y.; WU, N.; FU, Y.J. et al. Chemical composition and antimicrobial activity of the essential oil of Rosemary. Environ. Toxicol. Pharmacol., v.32, p.63-68, 2011. 
KHAN, A.; BASHIR, S.; KHAN, S.R. et al. Antiurolithic activity of Origanum vulgare is mediated through multiple pathways. BMC Complemen. Altern. Med., v.11, p.96p, 2011.

LUQMAN, S.; DWIVEDI, G.R.; DAROKAR, M.P. et al. Potential of Rosemary oil to be used in drug-resistant infections. Altern. Ther. Health Med., v.13, p.54-59, 2007.

MAIDA, I.; NOSTRO, A.; PESAVENTO, G. et al. Exploring the Anti-Burkholderia cepacia complex activity of essential oils: a preliminary analysis. Evid. Based Complement. Altern. Med., v.2014, n.ID 573518, p.1-10, 2014.

MARIMON, R.; CANO, J.; GENÉ, J. et al. Sporothrix brasiliensis, $S$. globosa and $S$. mexicana, three new Sporothrix species of clinical interest. J. Clin. Microbiol., v.45, p.3198-3206, 2007.

MARIMON, R.; SERENA, C.; GENÉ, J. et al. In vitro antifungal susceptibilities of five species of Sporothrix. Antimicrob. Agents Chemother., v.52, p.732-734, 2008.

MONTENEGRO, H.; RODRIGUES, A.M.; DIAS, M.A.G. et al. Feline sporotrichosis due to Sporothrix brasiliensis: an emerging animal infection in São Paulo, Brazil. BMC Vet. Res., v.10, p.269, 2014.

MOREIRA, M.S.C.; PAULINO, M.R.; CAVALCANTI, Y.W. et al. Atividade antifúngica de soluções antimicrobianas disponíveis comercialmente e de produtos naturais à base de Rosmarinus officinalis (alecrim). Int. J. Dent., v.11, p.38-42, 2012.

PEREIRA, S.A.; PASSOS, S.R.L.; SILVA, J.N. Response to azolic antifungal agents for treating feline sporotrichosis. Vet. Rec., v.166, p.290-294, 2010.

PRINS, C.L.; LEMOS, C.L.S.; FREITAS, S.P. Efeito do tempo de extração sobre a composição e o rendimento do óleo essencial de alecrim (Rosmarinus officinalis). Rev. Bras. Plant. Med., v.8, p.92-95, 2006.

REFERENCE method for broth dilution antifungal susceptibility testing of yeasts. M27A3 guideline. Approved standard. 3.ed. Wayne, PA: CLSI, 2008a. 25p.
REFERENCE method for broth dilution antifungal susceptibility testing for filamentous fungi. M38-A2 guideline. Approve standard. 2.ed. Wayne, PA: CLSI 2008b. 35p.

RODRIGUES, A.M.; DE HOOG, G.S.; CAMARGO, Z.P. Genotyping species of the Sporothrix schenckii Complex by PCR-RFLP of calmodulin. Diagn. Microbiol. Infect. Dis., v.78, p.383-387, 2014a.

RODRIGUES, A.M.; DE HOOG, G.S.; PIRES, D.C. et al. Genetic diversity and antifungal susceptibility profiles in causative agents of sporotrichosis. BMC Infect. Dis., v.14, p.219, 2014b.

RODRIGUES, A.M.; DE HOOG, S.; CAMARGO, Z.P. Emergence of pathogenicity in the Sporothrix schenckii complex. Med. Mycol., v.51, p.405-412, 2013.

SANTIN, R. Potencial antifúngico e toxicidade de óleos essenciais da família Lamiaceae. 2013. 106f. Tese (Doutorado em Ciências Veterinárias) - Faculdade de Veterinária, Universidade Federal do Rio Grande do Sul, Porto Alegre, RS.

SANTIN, R.; GIORDANI, C.; MADRID, I.M. et al. Antifungal activity of Origanum vulgare essential oil against Malassezia pachydermatis. Arq. Bras. Med. Vet. Zootec., v.66, p.367-373, 2014.

SIMÕES， C.M.O; SCHENKEL， E.P.; GOSMANN, G. et al. (Eds.). Farmacognosia: da planta ao medicamento. 5.ed. Porto Alegre: Editora da UFRGS, 2003. 1102p.

SOUZA, N.A.B.; LIMA, E.O.; GUEDES, D.N. et al. Efficacy of Origanum essential oils for inhibition of pottentially pathogenic fungi. Braz. J. Pharmacol. Sci., v.46, p.499-508, 2010.

VALE-SILVA, L.; SILVA, M.J.; OLIVEIRA, D. et al. Correlation of the chemical composition of essential oils from Origanum vulgare subsp. virens with their in vitro activity against pathogenic yeasts and filamentous fungi. J. Med. Microbiol., v.61, p.252-260, 2012.

VEIGA JR., V.F.; PINTO, A.C.; MACIEL, M.A.M. Plantas medicinais: cura segura? Quim. Nova, v.28, p.519-528, 2005. 